\title{
Mining, River Pollution and Disaster Risk Reduction: an Institutional Analysis
}

\author{
Moammed Irshad \\ Jamsetji Tata Centre for Disaster Management, Tata Institute of Social Science, India \\ *Corresponding Author:Mohammed.irshad@tiss.edu
}

Copyright (C) 2013 Horizon Research Publishing All rights reserved.

\begin{abstract}
Disaster risk reduction is an institutional intervention programme and there are both global and local strategies and approaches available. Regulating natural resource is one among them. This paper attempts to analyse the globally and nationally existing water governance approaches and their relative failure to impede the large scale river pollution in India's mining areas. The diversion of river for mining have resulted in multiple hazards in the mineral deposits areas of India. These approaches are advocating for 'sustainable development' and offer an institutional mechanism to integrate disaster risk reduction with environmental security. The regulatory measured are also being regulated by the economic interests of mining.
\end{abstract}

Keywords Mining, Disaster Risk, Pollution, Legitamization of Crisis, Displacement

\section{Introduction}

The mining areas are becoming conflict zones in India. This reason is applicable to all natural resource exploitation programs. In a developing society, ecological and social concern would be set aside for national wealth creation assuming that it would bring-in prosperity and development. The state with the help of all its apparatus is trying to establish the rationale of economy of mining and legitimizing the state policies towards mining. As Habermas (1979) argued 'the state compensates for dysfunctional consequences of the accumulation process that have elicited politically effective reactions on the part of individual capital groupings, organized labour or other organised groups. Thus, on the one hand, the state takes charges of the externalized consequences of private enterprises (ecological damage) or it secures the survival capacity of endangered sectors (mining and agriculture)'. The environmental and social consequences of mining have been considered as normal risk and the state is eager to implement policies to legitimize the consequences.
The environmental degradation resulting from larger scale mining put multiple hurdles on implementing disaster risk reduction (DRR) strategies. The global and the local DRR models such as Yokohama strategy, the Hyogo Framework for Action 2005-2015 and DRR practices of the Government of India proposed by state disaster management authorities seemed to have no institutional support system to put in place. Sustainable utilization of natural resources is one of the programmes of DRR; however, the mining areas in India seldom allow these programmes and policies to pursue. The paper deals disaster risk reduction not just interms of river flooding, rather it attempts to explains river pollution in the larger context of risks. It is about the institutional problems of implementing DRR strategies to prevent the river pollution in the mining regions in India. The paper is a review of the mining policy, water resource governance and DRR strategies with reference to river pollution.

\section{Methodology and Objectives}

The focus of this paper is the implementation of disaster risk reduction in the mining areas in India. The paper focuses on the river pollution across the mining areas in India. The large scale river pollution cannot be attributed to the lack of institutional regulatory mechanisms in India. Secondary data on river pollution and mining have been used for analysis. The first part of the paper reviews the current mining scenario of India and its impact on river stretches. This analysis has been followed by a critical view of the environmental and social consequences of the lack of implementation of the regulatory measures. The following are the research questions of the paper;

a) Why state is capable to override the regulatory measures?

b) What are the consequences of de-limiting the disaster reduction strategy as mere a post-disaster recovery project rather than ecological resilience?

c) Why right to natural resources is not considered as a disaster risk reduction strategy in India? 


\section{Mining, Environment and Society}

The definition of civil war may not fit into contemporary mining issues, however, if we look at the nature of involvement of political forces and state in India's mining areas indicate the presence of a silent civil war. In India mining industries are largely owned by government companies. Centre for Science and Environment's report (2010.24) has stated that, of the 25 percent of India's operational mines, the public sector alone controls 75 percent of the total value of mineral production. Mining and quarrying have destroyed 134307.23 hectares of forest land(1). The report further stated that, the significant aspect of the mining industry is its nearness to the tribals areas. 90 percent of India's coal and 80 percent of its other minerals are found in the tribal areas. The Indian mining industry is now open to private sector enterprises. Between 2002 and 2006 there were 540 mining clearances granted in India. Although the mining areas are developing the tribal who own the mining land are impoverished.

\subsection{Economics of Mining}

The mining industry is one of the oldest industries in India, which has more than 6000 years of experience. Centre for Science and Environment (CSE) (2008) on mining industries in India, referred that, the formal mining industry came along with independence. According to the CSE report the annual aggregate revenue from mining is worth Rs 580 million. Government of India had adopted a mining legislation in the 1950s and the 54 of list I of the Indian constitution have vested the right of regulating and developing mining with the central government. The 23 of list II in the seventh schedule has empowered the state government's control over the mining activities and mineral development subjected to the provision of List I of The Mines and Minerals (Development and Regulation Act, 1957.

India Mineral Conservation Rule-1960 (MCR) has delineated the responsibilities of the centre and state government under the federal system of India to deal with mining. According the MCR Rule of 1960, the Central Government of India has to control all mines excluding atomic minerals, and the state governments have been given the ownership and the responsibilities of minor minerals mining. This industry is an integral part of India's heavy industrial sector and its related contributions are spread across the country.

\subsection{Income from Mining}

Mining contributes to the Central Government and State Governments through the payment of royalty., dead rent, cess, sales tax, excise duties and custom duties. Of these, royalty is the major source of income. Royalty has been fixed on the amount of mineral extracted or consumed at the rate

Lok Sabha Unstarred Question No. 1612, dated on 07.03.2011.(down loaded form Indiastat.com (through TISS online resource)). specified in the second schedule of The Mines and Minerals (Development and Regulation) Act, 1957. Central government fixes royalty on major mines and state government fix royalty on minor mines. The royalty rate on major mines revises every three years. Dead rent is a charge generally paid by the leasee for the area included in the total mine area from where minerals are not extracted. The purpose of dead rent is to prevent the leasee from leaving the mine area idle. Reserve Bank of India's annual report (2011) mentioned that, India's mining sector is contributing 2.3 percentage of Gross Domestic Product. This is a significant contribution to the macro-economy of the nation. Income from mining to state is significantly less while comparing to the price of resources. See the table 1

\section{Mining and State Regulation}

The figure 1 shows the flow of mining legislation in India. The Mines and Minerals (Development and Regulation) Act, 1957 was passed by the parliament of India on 28th December 1957 for the regulation of mining and development of minerals. The Mines and Minerals (Development and Regulation) Act, 1957 has amended in five times-in 1972, 1986, 1994 and 1999. After each amendment, corresponding changes were carried out in the two rules, Mineral Conservation Rule (MCR) and Mineral Conservation and Development Rules. The 1972 and 1986 amendments had strengthened the government control and excluded the private sector. 1994 and 1999 amendment turned against the first two. The last two amendments gave significance to the private sector. According to the recent amendment, The Mines and Minerals (Development \& Regulation) Act, 2010, "allow free shares equal to twenty six percent in the company through the promoter's quota in case the holder of the lease is a company, or, an annuity equal to $26 \%$ of the profit after tax in the case holder of the lease is a person, on account of annual compensation". The history of amendment shows that it has been transferred from state control to private sector.

\section{Ecology, Water Resources and Mining}

The economic and legal institutions of mining have been well defined in the institutional structure of the state, however, there is a problematic phase of mining which is being set aside. This problematic phase has been disclosed by a committee appointed by the Ministry of Environment and Forest of Government of India led by NC Saxena in 2011. The Saxena committee has found the violation of; first) Scheduled Tribes and other Traditional Forest Dwellers (recognition of forest rights) Act, 2006. The e. Forest Right Act 2006 is considered to be the landmark in the history of tribal self rule in India, which is hitherto set aside. Second), Violation of Forest (conservation) Act - 1980; third) violation of Environment (protection) Act- 1986. 
Table 1. Royalty and revenue receipts ( In Rs Million)

\begin{tabular}{|c|c|c|c|c|c|c|c|c|c|}
\hline \multirow[b]{2}{*}{ States } & \multirow{2}{*}{$\begin{array}{l}2002-03 \\
\begin{array}{l}\text { Mineral } \\
\text { royalty }\end{array}\end{array}$} & \multirow{2}{*}{$\begin{array}{c}\text { 2003-04 } \\
\text { Total } \\
\text { revenue } \\
\text { receipt }\end{array}$} & \multicolumn{7}{|c|}{ 2004-05 } \\
\hline & & & $\begin{array}{c}\text { Royalty as } \\
\text { percentage } \\
\text { of total } \\
\text { revenue } \\
\text { receipt } \\
\end{array}$ & $\begin{array}{l}\text { Mineral } \\
\text { royalty }\end{array}$ & $\begin{array}{l}\text { Total } \\
\text { revenue } \\
\text { receipt }\end{array}$ & $\begin{array}{c}\text { Royalty as } \\
\text { percentage } \\
\text { of total } \\
\text { revenue } \\
\text { receipt } \\
\end{array}$ & $\begin{array}{l}\text { Mineral } \\
\text { royalty }\end{array}$ & $\begin{array}{l}\text { Total } \\
\text { revenue } \\
\text { receipt }\end{array}$ & $\begin{array}{c}\text { Royalty as } \\
\text { percentage } \\
\text { of total } \\
\text { revenue } \\
\text { receipt }\end{array}$ \\
\hline Chhattisgarh & 5524 & 54173 & 10.1 & 6372 & 59593.2 & 10.6 & 6946 & 72488.7 & 9.5 \\
\hline Jharkhand & 7977 & 74064.8 & 10.7 & 9002 & 74434.9 & 12.1 & 9162 & 68526.4 & 13.3 \\
\hline Orissa & 4406 & 84387.7 & 5.2 & 5472 & 94402.4 & 5.7 & 6636 & 118502 & 5.5 \\
\hline $\begin{array}{l}\text { Andhra } \\
\text { Pradesh }\end{array}$ & 7699 & 230029 & 3.3 & 7666 & 268685 & 2.8 & 8645 & 287495 & 3 \\
\hline Goa & 148 & 18330 & 0.80 & 179 & 16231.3 & 1.102808 & 174 & 18200.2 & 0.956033 \\
\hline
\end{tabular}

Sources: Rich Land Poor people. Centre for Science and Environment, 2008

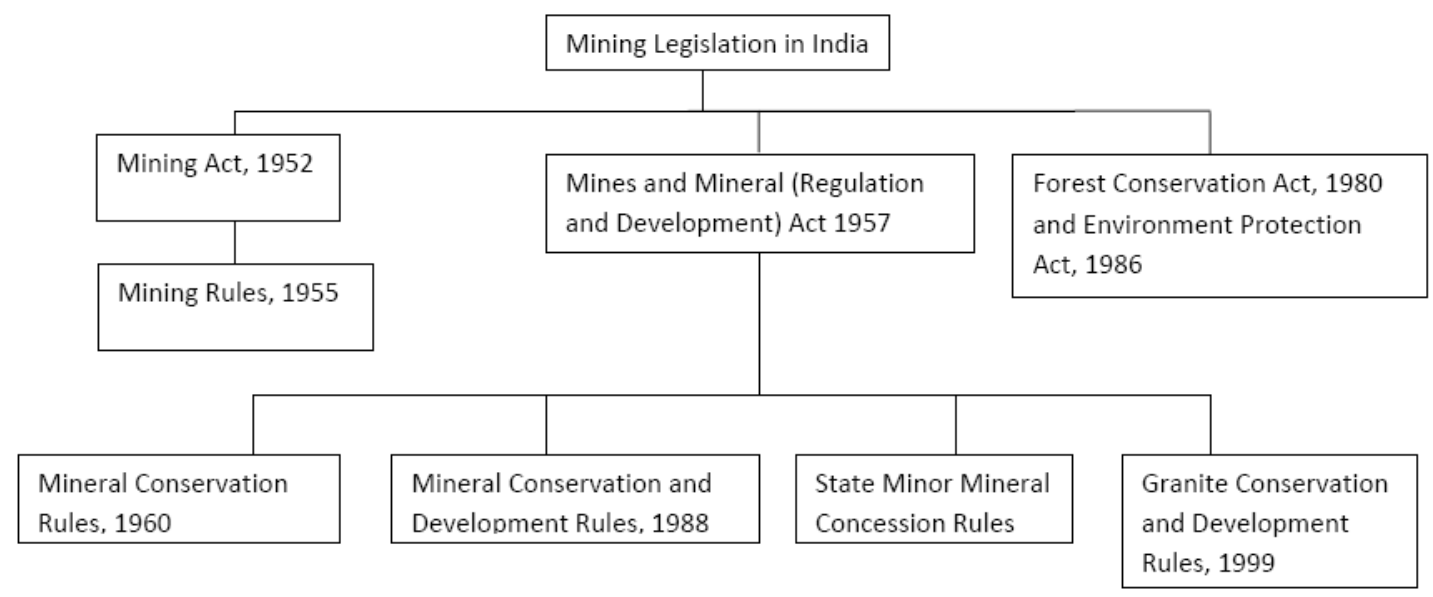

Source: CES, Rich Land Poor People 2008

Figure 1. Mining Legislation in India

The committee report is politically and economically significant with regards to the ecological impact of mining in India(2). It is the first comprehensive official report on the negative externalities of mining in India. The report stated that mining in the Niyamgiri Hills in the Orissa state of India has destroyed the ecology of 7 square kilometers of important wildlife habitat by clearing of 121000 trees. Besides, the committee paid heavy attention to the ecological impact on Niyamgiri hill top and its resultant implications on the region's water supply.

The ecological impact listed in the report is not limited to the Niyamagiri area; in fact all other mining sites in the country are under various kinds of ecological and social threats. The Central Ground Water Board (CGWB) has found that mining severely affects water tables as most of the

The fifth schedule of the Indian constitution ensures the right of self rule in areas which are come under the scheduled tribal areas. Mining areas in India are in the fifth schedule area, hence the forest diversion for mining and the larger scale displacement of tribal community is infact the violation of the constitutional rights of the tribal community. mining resources lie well below the water table(3). Still, according to the government sources there are about 15,000 illegal mines spread across the country as against 8,700 legal $\operatorname{mines}(4)$.

\subsection{Water Consumption}

Industries generally consume water, however, mining industry consume more water(5). Rubio and Lorca (1993) have quoted a study in 1978 which found that lignite mining in the Neyveli District in Tamil Nadu, a state of India, 40 submersible pumps had used to extract $9600 \mathrm{~m} 3 /$ hour of water which use to reduce the pressure of the underlying acidifier down to $1.5 \mathrm{~m}$ below the working level. The study further states that 24 tonnes of water were consumed for each

http://www frontlineonnet.com/f12714/stories/20100716271401200.htm $\mathrm{http}: / / w w w . f r o n t l i n e o n n e t . c o m / f 12714 /$ stories/20100716271400400.htm Miranda, Marta; Amanda Sauer; Deepa Shinde. Mine the Gap: Connecting Water Risk and Disclosure in the Mining Sector. Working Paper. World Resource Institute. 2010 
tonne of coal extracted. The study further states that mine developments and underground mine working below the practice level critically change the hydraulic gradation, hence affect the ground water and surface water flow regimes.

Chile (2004) in his study on limestone in the Coimbathore district of Tamil Nadu, state of India ,shows that mining left a deep pit up to $20 \mathrm{~m}$ from the general ground level which touched down to the groundwater level. The demand for limestone have resulted further exploitation of groundwater.

Sahu and Dash (2011) discuss that the coal mining in India generally removed about 500 million cubic meters (Mcum) of overburden to produce 260 MT of coal in 2004, the stripping ratio was $1.93 \mathrm{~m} 3$ (The ratio of overburden excavated to the amount of mineral removed is called the stripping ratio). Bauxite minerals are having higher stripping ratio. The highest stripping ratio means a higher rate of waste generation. These wastes are toxic in nature, it carries the metals such as mercury, arsenic, lead, zinc, cadmium etc. are finally contaminating the local environment. The details of water consumption of different minerals are given in Table 2 .

India's mineral reserves are in the areas which are either near the origin or the catchment of rivers. For instance, the lion's share of India's iron reserves are deposited in the courses and watershed of the Indravati River in Chhattisgrah State, Baitarni River in Orissa State, Tungabhadra River in Karnataka State and Mandovi in Goa State. About 80 percent of coal in Jharkhand and a major portion of the Raniganji coal field in West Bengal State lie within the Damodar valley river basin.

Table 2. Water consumption rate of different minerals

\begin{tabular}{|c|c|c|c|c|c|}
\hline S1 No & Mineral & Production (MT) & Overburden/ Waste (MT) & $\begin{array}{c}\text { Estimated land affected } \\
\text { (ha.) }\end{array}$ & $\begin{array}{c}\text { Norms used (land in } \\
\text { ha/MT of coal/ore }\end{array}$ \\
\hline 1 & Coal & 407 & 1493 & 10175 & 25 \\
\hline 2 & Limestone & 170.38 & 178.3 & 1704 & 10 \\
\hline 3 & Bauxite & 12.34 & 7.5 & 123 & 10 \\
\hline 4 & Iron ore & 154.4 & 143.9 & 1544 & 10 \\
\hline 5 & Others & 9.44 & 18.61 & & \\
\hline
\end{tabular}

Source: Sahu and Dash 2011

\subsection{The impact of Mining on Rivers}

\subsubsection{The Damodar Valley}

The Damodar Valley is India's largest mining area. There are 28 iron ore mines, 84 mica mines, 33 lime stock mines and five copper ore mines operating in the river basin. The Damodar valley is one of the most polluted rivers in India. The ministry of environment and forest (MoEF) has estimated the rate of silting in the river was more than seven million cubic metre $(\mathrm{mcm})$ as against designed rate of $0.84 \mathrm{mcm}(6)$. The MoEF has also assessed that mining and forest land diversion critically affected and polluted the river(7).

\subsubsection{The Mahanadhi and the Brahmani Rivers}

The Mahanadhi river is flowing over $141000 \mathrm{sq} \mathrm{km}$ covering the states, Chhattisgrah, Orissa and some areas of Jharkand and Maharashtra. There are two largest mining companies operating in the river basin. The National Aluminium Company Litmted (NALCO) is the major polluter of Brahmani river basin(8).

The number of polluted river stretches in 2004 was 71 and it increased to 150 in 2010, the table 3 tells the problems of river stretch pollution. Mining is not the only reason for all these river pollutions; however, the data indicate the absence of state regulations which would have reduced the pollution. 
Table 3. Selected State/River-wise Number of Polluted River Stretches in India

\begin{tabular}{|c|c|c|}
\hline \multicolumn{3}{|c|}{ (As on June, 2010) } \\
\hline States & River & $\begin{array}{l}\text { No. of Polluted } \\
\text { Stretches }\end{array}$ \\
\hline Andhra Pradesh & Godavari, Krishna, Manjira, Musi, Maner, Nakkavagu, Pennar and Tungabhadra & 9 \\
\hline Assam & Bharalu, Burhidihing, Deepar bill and Kalong & 4 \\
\hline Chandigarh & Attawa choe, Patiala ki Rao and Sukhna choe & 3 \\
\hline Delhi & Yamuna & 1 \\
\hline Gujarat & $\begin{array}{c}\text { Ambika, Anas, Amlakhadi, Bhogavo, Baleshwar Khadi, Dhadar, Daman Ganga, Khari, Kaveri, Kim, } \\
\text { Kolak, Mindhola, Mahi, Panam, Shedi, Sabarmati, and Tapi }\end{array}$ & 19 \\
\hline Haryana & Ghaggar, Gurgaon canal, Markanda, Western Yamuna canal, and Yamuna & 5 \\
\hline Himachal Pradesh & Beas, Markanda and Sukhna, & 3 \\
\hline Madhya Pradesh & Betwa, Chambal, Kshipra, Khan, Kalisot, Mandakini, Tons and Narmada & 9 \\
\hline Maharashtra & $\begin{array}{c}\text { Bhima, Godavari, Mula \& mutha, Pawana, Panchganga, Patalganga, Indrayani, Koyna, Kundalika, } \\
\text { Kalu, Kanhan, Kolar, Mithi, Tapi, Girna, Nira, Weinganga, Wardha, Krishna, Purna, Nira, } \\
\text { Chandrabhaga, Venna river, Ulhas, Rangavali and Bhatsa }\end{array}$ & 28 \\
\hline Punjab & Satluj and Ghaggar & 2 \\
\hline Tamil Nadu & Adyar, Coovum, Cauvery, Noyyal, Vaigai, Tambiraparani, Bhavani and Palar & 9 \\
\hline Uttar Pradesh & $\begin{array}{l}\text { Yamuna, Hindon, Western kali (Partly Covered), Kali nadi eastern, Bagad, Ganga, Gomti, Ramganga, } \\
\text { Saryu and Rihand }\end{array}$ & 12 \\
\hline Karnataka & Bhadra, Tunga, Tungabhadra, Laxmantirtha, Kali, Krishna, Hundri, Kundu, Arkavati and Malprabha & 11 \\
\hline Manipur & Nambul & 1 \\
\hline Rajasthan & Bandi, Berech, Jojari, Chambal and Khetri & 5 \\
\hline Uttarakhand & Kosi, Dhela \& kichha and Bahalla & 3 \\
\hline Jharkhand & Subarnrekha and Sankh & 2 \\
\hline Kerala & Karamana, Puzhackal and Kadambayar & 3 \\
\hline Tripura & Agartala canal and Haora & 2 \\
\hline Bihar & Sikrana & 1 \\
\hline Chattisgarh & Arpa, Seonath and Mahanadi & 3 \\
\hline Meghalaya & Kharkhala and Umtrew & 2 \\
\hline Orissa & Kathjodi, Brahmani, Mahanadi and Kuakhai & 4 \\
\hline Pondicherry & Arasalar & 1 \\
\hline West Bengal & Damodar, Ganga and Barakar & 3 \\
\hline Nagaland & Dhansiri & 1 \\
\hline Sikkim & Dikchu, Teesta, Maney khola and Ranichu & 4 \\
\hline India & & 150 \\
\hline
\end{tabular}




\section{Law, Policy and State}

The purpose of putting all the relevant data on river pollution and water consumption is to analyse the poor governance of natural resources. The following declarations on water are having the capacity to regulate and suggest for sustainable use of river water in the mining area.

\subsection{The Major Declarations in Water Governance}

- The Delft Declaration (1991) - this identified the weakness of the institutional capacity as the main cause of unsustainable water services and supported capacity building and integrated planning.

- The Dublin Principles (1992)- this endorses political commitments regarding the involvement of government and community towards institutional changes, the use of market economy, capacity building etc.

- The UN conference on Environment and Development ( Earth Summit)(1992)- the agenda 21 gave priority to adjustment of decision making systems and institutional arrangements at the country level to deal with the emerging environmental and other issue of the twenty first century.

- Water resources management- a policy paper (1993)this World Bank policy paper captured the Dublin Principles and laid down the policy for the WB to promote and support national water sector policies.

- The global water partnership-technical advisory committee (GWP-TAC) 'Background paper No 4: technical guidelines for integrated water resources management' -these define the process of the India water resources association (IWRA) and lays down the types of integration envisaged and the limitation of such integration

- World Water Forum-1 Morocco 1997

- Preparation of world water vision on water, food, and rural development (international commission on irrigation and drainage (ICID) (2000)-this vision stressed the need for continued irrigation expansion, increasing storages, and additional irrigation water use even after management improvement.

- The preparation of integrated world water vision (world water council) (2000)-the consolidated vision presumed that there is no need for any significant addition towards agriculture water use.

- World Water Forum-II, the Hague (2000) the sectoral vision for water use sectors and the consolidated vision were released.

- The international conference on fresh water, Bonn (2001)-brought out five thematic background papers

- The Rio plus ten conferences, Johannesburg (2002)-reviewed agenda 21 and laid down action plans for implementation of the agenda by the nations of the world.

- World water forum-III, Kyoto (2003)-relooked at the world water vision. Needs of the developing countries with growing populations were recognised (Briscose and Malik, 2007)

Apart from these declarations some of the approache and policy documents are also offered comprehensive water resource governances. Integrated Water Resource Management Framework is prominent among them. Though there are different definitions on IWRM, the definition by the Global Water Partnership (GWP) has been accepted as a universal definition of IWRM following the RIO conference on Sustainable Development in 1992. As per this, IWRM is defined as: "a process which promotes the co-ordinated development and management of water, land and related resources in order to maximize the resultant economic and social welfare in an equitable manner without compromising the sustainability of vital eco-systems( 9 )". Apart from IWRM, India's national water policy 2002 and the 2012 have also paid attention towards the sustainable utilisation of water resources. However, this paper does not fully agree with all the provisions of the above mentioned declarations and approaches, for instance the water policy 2002 stated that, "water is a prime natural resource, a basic human need and a precious national asset. Planning, development and management of water resources need to be governed by national perspectives". The draft for National Water Policy 2012 begins with a sensitive note and comment on ecology and livelihood. The draft points out that, ecological needs of the river should be determined recognizing that the natural river flows are characterized by low or no flows, small floods (freshets), large floods, etc., and should accommodate developmental needs. A portion of river flows should be kept aside to meet ecological needs ensuring that the low and high flow releases are proportional to the natural flow regime, including base flow contribution in the low flow season through regulated ground water use (10).

The 2002 Water Policy had not supported water privatization. The national water policy draft 2012 has suggested water privatisation as a strategy. The draft proposes water pricing as a tool to promote efficient use and maximize the value of water. According to the draft "the "Service Provider" role of the state has to be gradually shifted to that of a regulator of services and facilitates for strengthening the institutions responsible for planning, implementation and management of water resources. The water related services should be transferred to community and / or private sector with appropriate "Public Private Partnership" model (11)". The National Water policy 2012 is also reflects the changing role of state in the water resource regulation. The 2012 Water Policy document is infact support the main argument of this paper i.e the economic interest of natural resource governance. The coming part discusses this in detail.

Source Integrated Water Resources Management in Action. WWAP, DHI Water Policy, UNEP-DHI Centre for Water and Environment. 2009

The Draft for National Water Policy 2012

The Draft for National Water Policy 2012 


\section{DRR Strategies, Mining and River Pollution}

Disaster Risk Reduction (DRR) is a comprehensive strategy. For instance the Yokohama strategy puts in place a plan of action to stop the rising death toll and economic loss due to natural disasters. The strategy has advocated the participation of the global community towards this. The resolution 46/182 of General Assembly passed in 19th December 1991 had agreed to advocate for an integrated approach which ensures an international understanding of prevention. The major thrust of this strategy is that it gives emphasis on sustainable development, according to which, 'sustainable economic growth and sustainable development can't be achieved in many countries without adequate measures to reduce disaster losses, and that there are close linkages between disaster losses and environmental degradation'. The environmental degradation has been given due importance in this strategy. Although India is signatory of these treaties, still the government has not faced any issue in continuing with the current system of mining.

The Hyogo Framework for Action 2005 and 2015, another major global accord on DRR has also become unfit in the mining area. This framework is also talking about actions and approaches to contextualize disaster risk in sustainable development and also advocate the process of building resilience through enhanced national and local capabilities to manage and reduce the risk. It also emphasizes the importance of budgetary support for DRR strategies. The net income from mining is never ever enough to meet the DRR even in the mining area, so, additional budgetary support should be allocated. The increasing negative return to the capital stock of these areas necessitates additional budgetary allocations to meet the running expenditure of alternative institutions. However the country like India can't afford this increasing budget support for DRR. Infact this is part is completely being missed in the economics of mining and DRR practice.

Apart from these global strategies, the Disaster Management Act 2005 in India legitimised the DRR practice as government programme. For instance, the act helped set up separate disaster management authorities in each state, moreover the Act states that the prevention and mitigation of disaster 'shall be the responsibility of every ministry or department of the government of India to take measures for preparation of disaster, mitigation and capacity building'. The act envisages National Disaster Response Fund and National Disaster Mitigation Fund for prevention, mitigation and preparedness. The DM Act's major thrust is to set up a separate institution for disaster management and disaster risk reduction. The Act has not paid due attention on natural resources protection per se, however, the local self government has given the power to ensure natural resource protection as part of preventions.

DRR as an institutional approach has been ensured in these strategies. The state and international agencies are equipped with institutional and financial resources to integrate disaster risk reduction in developmental programme. All these measures are capable to build environmental resilience. The given regulatory framework and policies are offering adequate institutional support to implement a sustainable mining process. The whole concept and practice of sustainable and regulated mining have been set aside. It prove that the absence of DRR in the mining areas is not due to any lack of institutional support. The principle of DRR is much more effective in implementing a sustainable method of natural resource utilisation and it is primarily a state driven policy in India. The economic interest of private sector is able to regulate the public governance.

\section{Concluding Observations}

Accidents in the mining areas are generally considered as mining disasters; however, this paper has chosen the river pollution due to mining as a disaster. The rivers stretches along the mining areas are heavily contaminated and make life difficult for the people who live and depended on the embankments. This is infact a disaster to the local community. The social resilience of the community is an environmental resilience too. The right to sustainable access to resources as resilience have not yet been discussed in the disaster risk reduction perspective. The general approach toward DRR have completely insignificant with regards to the massive river pollution. The mining industries have set up a parallel economic order. The industry is growing with disaster risk.

The right to natural resources as DRR should be institutionalised in the disaster risk mitigation framework. This cannot be implemented without putting substantial efforts in institutional and organizational nature of the state apparatus. The state apparatus of India at present follow economic interest rather than ecology and environment. The increasing economic interests on mining and natural resources contamination push the mining areas into ecological conflicts. This conflict could be considered as demand for DRR. Otherwise Disaster Risk Reduction would limit to post-disaster reconstruction only and it gradually lose its significance in regulating resource utilisation.

\section{REFERENCES}

[1] Adger, W. Neil.2000. Institutional Adaptation to Environmental Risk under the Transition in Vietnam. Annals of the Association of American Geographers, Vol. 90, No. 4 (Dec., 2000), pp.738-758

[2] Briscose, John and R P S Malik (2007) "Hand book of Water resources in India". OUP.

[3] Buckley, Geoffrey L. April, 1998. Society The Environmental Transformation of an Appalachian Valley, 1850-1906. Geographical Review, Vol. 88, No. 2, Historical 
Geography and Environmental History pp. 175-198

[4] Chaulya, S. K. 2004. Water resource accounting for a mining area in India. Environmental Monitoring and Assessment 93: 69-89, 2004

[5] Dickens, Paul S; Roger A. Minear and Bruce A. Tschantz . 1989. Hydrologic Alteration of Mountain Watersheds from Surface Mining. Journal (Water Pollution Control Federation), Vol. 61, No. 7 (Jul., 1989), pp. 1249-1260

[6] Hodges, Carroll Ann.1995. Mineral Resources, Environmental Issues, and Land Use.

[7] Science, New Series, Vol. 268, No. 5215 (Jun. 2, 1995), pp. $1305-1312$

[8] Hyogo Framework for. Action 2005-2015: ISDR. International Strategy for Disaster Reduction. International Strategy for Disaster Reduction

[9] Integrated Water Resources Management in Action. WWAP, DHI Water Policy, UNEP-DHI Centre for Water and Environment. 2009

[10] Kreps, G. A. 1984. Sociological Inquiry and Disaster Research. Annual Review of Sociology, Vol. 10 (1984), pp. 309-330

[11] Miranda, Marta; Amanda Sauer; Deepa Shinde. Mine the Gap: Connecting Water Risk and Disclosure in the Mining Sector. Working Paper. World Resource Institute. 2010

[12] Ramakrishnan, Venkitesh. 2010. Plunder and profit: Indiscriminate and illegal mining, aided by the corporate-political nexus, causes extensive damage to livelihoods and the environment. Frontline Magazine. Volume 27 - Issue 14 : Jul. 03-16, 2010

[13] Rubio, Rafael Fernandez and David Fernandez Lorca. 1993. Mine water drainage.
[14] Mine water and Environment. Vol 12 Annual Issue 1993, pp 107-130

[15] Rich Land Poor People: Is sustainable mining possible ? Centre for Science and Environment, New Delhi. 2008

[16] Reserve Bank of India: Annual report 2011

[17] Saxena, N C; Parasuraman, S; Promode Kant; Amita Baviskar. Report Of The Four Member Committee For Investigation Into The Proposal Submitted By The Orissa Mining Company For Bauxite Mining In Niyamgiri . 2010. Ministry of Environment \& Forests, Government of India

[18] Sahu, H. B and S. Dash. 2011. Land Degradation due to Mining in India and its Mitigation Measures. 2nd International Conference on Environmental Science and Technology

[19] IPCBEE vol.6 (2011) (C) (2011) IACSIT Press, Singapore

[20] Sreedhar, r. 2010. The way ahead: A moratorium on new mines until the contentious issues relating to the mining sector are resolved is the need of the hour. Frontline Magazine. Volume 27 - Issue 14 :: Jul. 03-16, 2010

[21] Szablowski, David. 2002. Mining, Displacement and the World Bank: A Case Analysis of Compania Minera Antamina's Operations in Peru .Journal of Business Ethics, Vol. 39, No. 3, Resource Extraction Industries in theDeveloping World (Sep., 2002), pp. 247-27

[22] Habermas, Jurgen.1979. Legitimation Crisis. Polity Press

[23] Lok Sabha Starred Question No. 41, dated on 28.07.2010 accessed through TISS online date sources on 12/06/2012

[24] Yokohama Strategy and Plan of Action for a Safer World. Guidelines for Natural Disaster Prevention, Preparedness and Mitigation 